\title{
The influence of lovastatin on thrombomodulin gene expression in vascular endothelial cells - in vitro study
}

\author{
Krzysztof Góralczyk¹, Krystyna Soszyńska², Olga Haus², Robert Bielis², \\ Danuta Rość1
}

${ }^{1}$ Depatment of Pathophysiology, ${ }^{2}$ Depatment of Clinical Genetics, Nicolaus Copernicus University in Torun, Collegium Medicum in Bydgoszcz, Bydgoszcz, Poland

\begin{abstract}
Objective: Statins reduce lipids concentration in blood. The latest investigations show they also improved the function of vascular endothelial cells (ECs). Thrombomodulin (TM) is particularly important marker of ECs activity. We investigated the in vitro effect of lovastatin on the expression level of TM gene.Methods and results: ECs were incubated for $24 \mathrm{~h}$ in culture medium including lovastatin in 3 concentrations: 0.1, 1.0, $10.0 \mathrm{~mol} / 1$. The mRNA level of TM increased in correlation with rising concentrations of lovastatin to $600 \%$ vs. control group. Conclusions: TM is essential antithrombotic factor in endothelial cells. Lovastatin significantly raises thrombomodulin gene expression. It is important characteristics of this medicine, which prevents cardiovascular events.
\end{abstract}

Key words: lovastatin, thrombomodulin gene expression, endothelium

\section{Introduction}

Endothelial cells are essential for coagulation and fibrinolysis processes. Their function disturbances lead to atherosclerosis [1] which is still the leading cause of death in the world.

Thrombomodulin (TM) is a marker of endothelial cells damage. TM is a transmembrane glycoprotein with antithrombotic properties. It inhibits thrombin which is the main factor of thrombus formation. Thrombin and thrombomodulin fusion on endothelial cells surface changes thrombin function from thrombotic to antithrombotic. It could be realized by protein $\mathrm{C}$ activation. The activated form (with protein $\mathrm{S}$ and phospholipid as cofactors) degrades Factor Va and Factor VIIIa and inactivates tissue factor plasminogen inhibitor [2,3].

Lovastatin is one of the statins representatives. The statins significantly reduce cholesterol level and significantly lower morbidity and mortality related to cardiovascular events $[4,5]$. They improve endothelium function, inhibit macrophages and smooth muscles cells proliferation and migration [6], influence hemo-

Correspondence: K. Góralczyk, Dept. of Pathophysiology, Collegium Medicum Skłodowskiej-Curie 9, 85-094 Bydgoszcz, Poland; tel.: (+4852) 5853476, fax.: (+4852) 5853595,

e-mail: krzyg@cm.umk.pl stasis and inflammation processes, stabilize atherosclerotic plaques [7-12].

The influence of statins on genes related to hemostasis was investigated in relation to thrombomodulin, eNOS, E-selectin, PAI-1, VCAM-1, ICAM-1, endothelin [9,10,13-19].

All investigators are unanimous that all kinds of the statins function are similar but differ in strength of influence [9]. The influence of lovastatin on hemostasis, especially on thrombomodulin was rarely presented. The aim of our in vitro study was an assessment of influence of increasing lovastatin concentrations on TM gene expression in endothelial cells. The experiment is a continuation of our earlier investigations [20].

\section{Materials and methods}

Cells. Endothelial cells were derived from human umbilical veins by enzyme method using collagenase. Cells were placed in growth medium consisting of medium M199, fetal bovine serum (FBS) $20 \% \mathrm{v} / \mathrm{v}$ and penicillin $100 \mathrm{IU} / \mathrm{ml}\left(\mathrm{Gibco}^{\mathrm{TM}}\right)$ with addition of $50 \mu \mathrm{g} / \mathrm{ml}$ of Endothelial Cell Growth Supplement (ECGS - Biomedical Technologies Inc. USA) and heparin (according to method described in ref. 20). Cultures were placed in an incubator at $37^{\circ} \mathrm{C}$ with $5 \% \mathrm{CO} 2$ and a tray of water in the bottom for humidity. After 2-4 passaging cells were used for experiment. Cells were incubated with various concentrations of lovastatin: $0.1,1.0$ and $10.0 \mu \mathrm{mol} / 1$. The experimental culture (with addition of lovastatin) and control culture (without lovastatin) were incubated for $24 \mathrm{~h}$. 


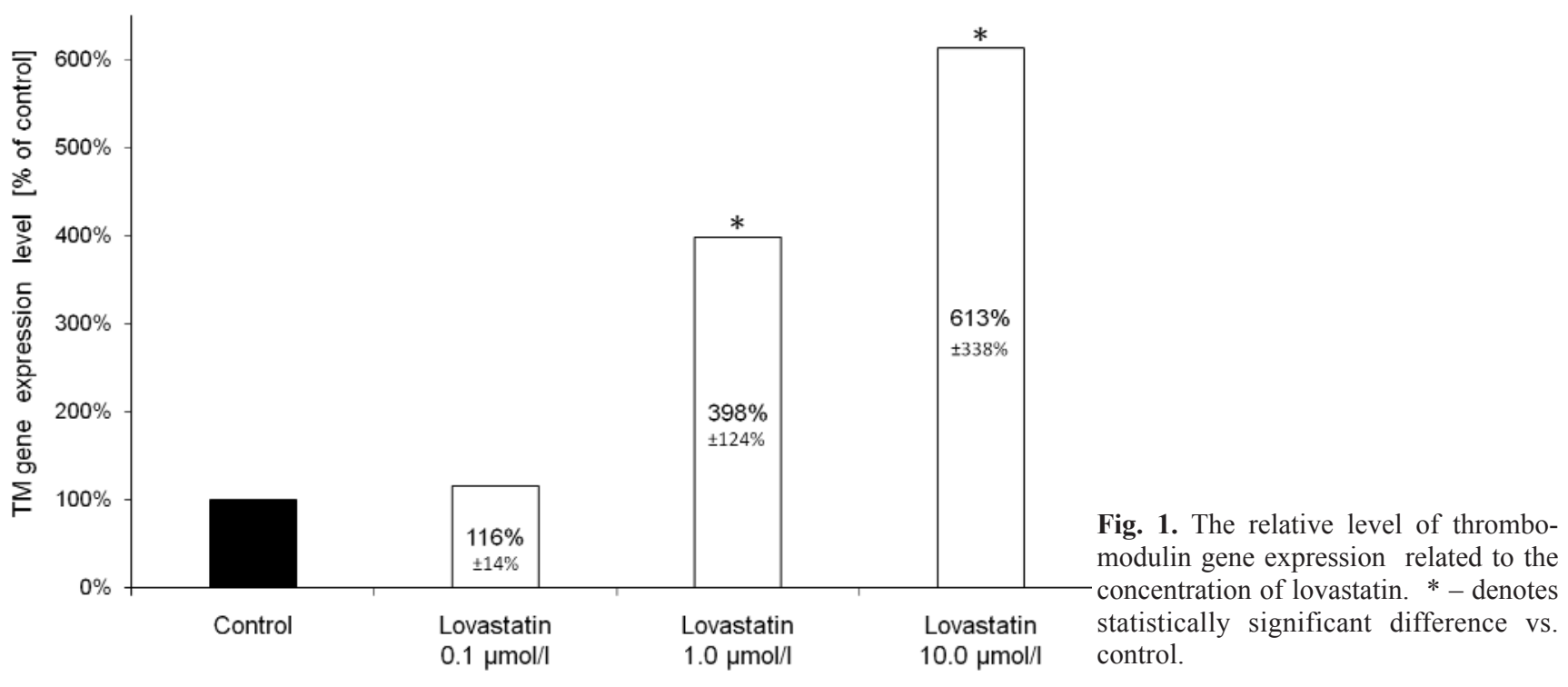

Gene expression. The next step was quantitative assessment of TM gene expression. For total RNA isolation the SV Total Isolation Kit was used. To synthesize cDNA $1 \mu \mathrm{g}$ of total RNA, $25 \mu \mathrm{M}$ random primers, 100 units SuperScript RT III, 20 units RNAsin, $1 \mathrm{mM}$ dNTP and RT buffer in final volume of $20 \mu 1$ were used. The reverse transcription was performed in $50^{\circ} \mathrm{C}$ for 50 minutes. The final cDNA was diluted with $30 \mu 1$ of $\mathrm{H}_{2} \mathrm{O}$. RQ-PCR reaction was carried out in $25 \mu \mathrm{l}$ reaction mixture with $4 \mu \mathrm{l} \mathrm{cDNA}, 200 \mu \mathrm{M}$ dNTP, 1unit of Platinum Taq polymerase, $5 \mathrm{mM} \mathrm{MgCl}_{2}, 300 \mu \mathrm{M}$ TM primers (TM-F 5'-GATGACTGCATACTGGAGCC-3', TM-R 5'-CACACTCGCCGTCCACCAG-3', Gene Bank XM 009595), 300 M GAPDH primers (GAPDH-F 5'-GTGAACCAT GAGAAGTATGAC-3', GAPDH-R 5'CACACTCGCCGTCCACC AG-3', Gene Bank XM 006959) and 200 mM TM TaqMan probe (FAM-cacagggtggettcgagtgccac-TAMRA, Gene Bank XM 009595), $200 \mathrm{mM}$ GAPDH TaqMan probe (FAMCCAACTGCTTAGCACCCCTGGCC-TAMRA, Gene Bank XM 006959). The reaction conditions were $50^{\circ} \mathrm{C}$ for $2 \mathrm{~min}$ and $95^{\circ} \mathrm{C}$ for $10 \mathrm{~min}$, followed by 50 cycles of $95^{\circ} \mathrm{C}$ for $15 \mathrm{~s}$ and $60^{\circ} \mathrm{C}$ for 60 $\mathrm{s}$ for annealing and extention.

Results were assessed using $\Delta \Delta \mathrm{Ct}$ method which is a relative transcript quantification using $\mathrm{Ct}$ value of thrombomodulin gene (TM) comparing to reference gene GAPDH.

Lovastatin was received from Grodziskie Zakłady Farmaceutyczne "Polfa" Sp. z o.o. from Grodzisk Mazowiecki, Poland.

Ethical issues. The study obtained the approval of the local Ethics Committee at Collegium Medicum in Bydgoszcz of Nicolaus Copernicus University in Torun 31.03.2005, registry number $\mathrm{KB} / 219 / 2005$.

Statistical analysis. Statistical analysis was performed using Statistica for Windows (StatSoft Inc.) The results are presented as mean \pm SEM from three experiments. ANOVA test was used in the statistical analysis. Differences were considered statistically significant when $\mathrm{p}<0.05$.

\section{Results}

The increasing doses of lovastatin caused progressing TM gene expression rise. Fig. 1 shows the results of three experiments which are compared to controls val- ues (culture without lovastatin) and showed as percentage. The lowest dose of lovastatin $(0.1 \mu \mathrm{mol} / \mathrm{l})$ caused increase of TM gene expression of about $120 \%$ (not significant), higher doses (1.0 and $10.0 \mu \mathrm{mol} / \mathrm{l}) 400 \%$ and $600 \%$, respectively $(\mathrm{p}<0.05)$. Differences between the lowest dose and higher doses ware statistically significant $(\mathrm{p}<0.05)$, however differences between doses 1.0 and $10.0 \mu \mathrm{mol} / 1$ were not significant.

\section{Discussion}

The statins are group of drugs of natural and synthetic origin. Most of studies did not show any significant differences in the function of individual statins, they show similar pharmacologic effect. The strength of effectiveness depends on the statins kind [9]. Our study was carried out using lovastatin of Polish pharmaceutical company POLFA Grodzisk. Most investigators used pitavastatin $[9,13,15]$ and atorvastatin [13$15,18]$. Our in vitro study shows lovastatin influence on trombomodulin mRNA concentration in endothelial cells which was dependent on drugs dose (Fig. 1). TM gene expression rose progressively from $116 \%$ to $613 \%$ comparing to controls as higher doses of lovastatin were added. Statistically significant differences were obtained between the lowest dose of statin $(0.1 \mu \mathrm{mol} / \mathrm{l})$ and higher doses $(1.0$ and $10.0 \mu \mathrm{mol} / \mathrm{l})$, $(\mathrm{p}=0.0495)$. Threefold increase of TM gene expression after 24 hours incubation of endothelial cells with lovastatin $(10.0 \mu \mathrm{mol} / \mathrm{l})$ comparing to control cells was reported by van Thienen [16]. The other statins also caused several or even more than ten times increase [9,13-15].

The induction of the increase of gene expression of TM which has the antithrombotic properties is an important function of lovastatin. Statins also cause a decrease of expression of prothrombotic factors such 
as: E-selectin, PAI-1, VCAM-1, ICAM-1, endothelin $[13,15,17-19]$ and an increase of eNOS gene expression. Some investigators suggested that eNOS expression is strictly connected with TM expression $[14,16]$. NO is an important endothelial factor which improves the function of endothelium by its antithrombotic and antiatherogenic action.

Wide spectrum of the functions of statins is difficult to explain only by their influence on lipid concentration. These drugs lower the cholesterol level by inhibiting the enzyme HMG-CoA reductase and have the influence on posttranslational proteins prenylation by Farnezyl-PP and Geranylgeranyl-PP which are products in cholesterol synthesis pathway. This mechanism is probably responsible for pleiotropic statins effect on different type of cells $[21,22]$.

Our previous works showed an increased concentration of TM protein on endothelial cells surface after lovastatin exposition [20]. In the current study we showed also lovastatin dose-dependent increase of TM mRNA concentration which means an increased TM gene expression and an increased production of inhibitory protein. The increase of the expression of this thrombin receptor means higher potential inhibitory abilities of thrombomodulin as an effect of increasing lovastatin doses.

Summarizing, the explicit rise of TM gene expression as an effect of lovastatin action is a real proof of inhibitory function on blood hipercoagulability of this drug.

\section{References}

[ 1] Schumacher A, Seljeflot I, Sommervoll L et al. Increased levels of endothelial haemostatic markers in patients with coronary heart disease. Thromb Res. 2002;1:25-31.

[2] Esmon C T. The protein C pathway. Chest. 2003;124(3 Suppl):26-32.

[3] Pearson J D. Endothelial cell function and thrombosis. Bailliere's Clin Haematol. 1999;12:329-41.

[4] Scandinavian Simvastatin Survival Study Group. Randomised trial of cholesterol lowering in 4444 patients with coronary heart disease: the Scandinavian Simvastatin Survival Study Group. Lancet. 1994;344:1383-1389.

[5] Shepherd J, Cobbe S M, Ford I et al. Prevention of coronary heart disease with pravastatin in men with hypercholesterolemia. West of Scotland Coronary Prevention Study Group. N Engl J Med. 1995;33:1301-1307.

[6] Corsini A, Bellosta S, Baetta R et al. New insights into the pharmacodynamic and pharmacokinetic properties of statins. Pharmacol Ther. 1999;84:413-428.

[ 7] Eto M, Kozai T, Cosentino F et al. Statin prevents tissue factor expression in human endothelial cells. Circulation. 2002;105:1756-1759.
[ 8] Koh K K. Effects of HMG-CoA reductase inhibitor on hemostasis. Int J Cardiol. 2000;76:23-32.

[ 9] Masamura K, Oida K, Kanehara $\mathrm{H}$ et al. Pitavastatin-induced thrombomodulin expression by endothelial cells acts via inhibition of small $\mathrm{G}$ proteins of the Rho family. Arterioscler Thromb Vasc Biol. 2003;23:512-517.

[10] Rasmussen L M, Hansen P R, Nabipour M T et al. Diverse effects of inhibition of 3-hydroxy-3-methylglutaryl-CoA reductase on the expression of VCAM-1 and E-selectin in endothelial cells. Biochem J. 2001;360:363-370.

[11] Rezaie-Majd A, Maca T, Bucek R A et al. Reduced expression of cytokines interleukin-6, interleukin-8, and monocyte chemoattractant protein-1 in circulating monocytes from hypercholesterolemic patients. Arterioscler Thromb Vasc Biol. 2002;22:1194-1199.

[12] Van Nieuw Amerongen G P, Vermeer M A, N?gre - Aminou $\mathrm{P}$ et al. Simvastatin improves disturbed endothelial barrier function. Circulation. 2000;102:2803-9.

[13] Morikawa S, Takabe W, Mataki C et al. Global analysis of RNA expression profile in human cells treated with statins. J Atheroscler Thromb. 2004;11:62-72.

[14] Shi J, Wang J, Zheng H et al. Statins increase thrombomodulin expression and function in human endothelial cells by a nitric oxide-dependent mechanism and counteract tumor necrosis factor alpha-induced thrombomodulin downregulation. Blood Coagul Fibrin. 2003;14:575-585.

[15] Morikawa S, Takabe W, Mataki C et al. The effect of statins on mRNA levels of genes related to inflammation, coagulation, and vascular constriction in HUVEC. $J$ Atheroscler Thromb. 2002;9:178-183.

[16] Van Thienen J V, Fledderus J O, Dekker R J et al. Shear stress sustains atheroprotective endothelial KLF2 expression more potently through mRNA stabilization. Cardiovasc Res. 2006; 72:231-240.

[17] Zapolska-Downar D, Siennicka A, Kaczmarczyk M et al. Simvastatin modulates TNF alpha-induced adhesion molecules expression in human endothelial cells. Life Sci. 2004; 75:1287-302.

[18] Lopez S, Peiretti F, Bonardo B et. al. Effect of atorvastatin and fluvastatin on the expression of plasminogen activator inhibitor type-1 in cultured endothelial cells. Atheroscler. 2000;152:359-66

[19] Nübel T, Dippold W, Kleinert H et al. Lovastatin inhibits Rho-regulated expression of E-selectin by TNF alpha and attenuates tumor cell adhesion. FASEB J. 2004;18:140-2.

[20] Góralczyk K, Bielis L, Kotzbach R et al. The influence of lovastatin on viability of vascular endothelial cells culture and on components of anticoagulant protein $\mathrm{C}$ system - in vitro study [Pol. non Eng.]. Med Biol Sci. 2007;21:37-42.

[21] Stancu C, Sima A. Statins: mechanism of action and effects. J Cell Mol Med. 2001;5:378-387.

[22] Landsberger M, Jantzen F, Konemann S et al. Blockade of geranylgeranylation by rosuvastatin upregulates eNOS expression in human venous endothelial cells. Biochem Biophys Res Commun. 2005;336:1005-9.

Submitted: 28 April, 2008 Accepted after reviews: 5 October, 2008 